OPEN ACCESS

Edited by:

J. B. Ruhl,

Vanderbilt University, United States

Reviewed by:

Kalyani Robbins,

Loyola University Chicago,

United States

Eric Biber,

University of California, Berkeley,

United States

*Correspondence:

Karrigan Bork

ksbork@ucdavis.edu

tThese authors have contributed equally to this work and share first authorship

Specialty section:

This article was submitted to

Climate Risk Management,

a section of the journal

Frontiers in Climate

Received: 01 June 2021

Accepted: 23 July 2021

Published: 01 September 2021

Citation:

Bork K and Hirokawa K (2021) Trends in Local Ecosystem Governance.

Front. Clim. 3:719150.

doi: 10.3389/fclim.2021.719150

\section{Trends in Local Ecosystem Governance}

\author{
Karrigan Bork ${ }^{1 * t}$ and Keith Hirokawa ${ }^{2 t}$ \\ ${ }^{1}$ School of Law \& Center for Watershed Sciences, University of California, Davis, Davis, CA, United States, ${ }^{2}$ Albany School of \\ Law, Albany, NY, United States
}

The physical and biological factors that together determine ecosystem structure and function will be subject to enormous pressures under future climate regimes. These pressures will impact ecosystem processes and services, ranging from impacts on biodiversity to loss of essential ecosystem benefits. Ecosystem management to maintain desired ecosystem conditions will become increasingly important. Existing governance structures are insufficient to provide the necessary guidance for these management efforts. The legal literature is increasingly focused on local ecosystem governance as a viable option to fill this governance gap. For example, increasing recognition of the value of ecosystem services to local communities has driven increased efforts to protect those services through local ecosystem initiatives. The local ecosystem governance scholarship is diffuse, making the literature difficult to access. Based on a review of the legal literature on local ecosystem governance over the last 20 years, this article marshals the theoretical arguments for and against local governance and identifies ongoing efforts to implement local ecosystem governance. The article also identifies both emerging challenges to local ecosystem governance and potential ways to address those challenges. From this review emerges actionable recommendations and critical research needs to improve local ecosystem governance.

Keywords: ecosystem, governance, local, collaborative, watershed, ecosystem services

\section{INTRODUCTION}

Ecosystems consist of the organisms in a given space interacting with their physical environment (Odum and Barrett, 2005). Ecosystems are nested units, defined based on characteristics of interest, so they can be very small, like the gut biome of an individual person, or very large, like the arctic tundra. The characteristics of a given ecosystem - the particular mix of species, in their particular abundance, the system's overall productivity and resilience-depend on a host of factors. These primarily include the physical characteristics of the system like climate, disturbance regime, or soil chemistry, and the species availability and interactions between the species (Stokstad, 2009). For example, the mix of trees growing in a forest depends on the region's physical characteristics, on the species available to colonize the forest, and on interactions between the trees and other living organisms in the forest. Altering any aspect of the physical or biological components is likely to change the characteristics of the resulting ecosystem. Our world's changing climate will alter core aspects of virtually every ecosystem on the planet (Ruhl and Salzman, 2010); existing climate change has already altered $82 \%$ of core ecological processes worldwide (Scheffers et al., 2016). These changes will play out in untold ways across ecosystems everywhere. 
Ecosystem changes create significant risks. Humans are part of ecosystems and rely on ecosystems both for necessary goods, like lumber or fish or oxygen, and for necessary services, like flood control, carbon sequestration, aesthetics, and support of biodiversity (Guswa et al., 2014). Ecosystems also provide nonmarket value, often deeply tied to the nature of a location, like California's coastal redwoods or the Great Smoky Mountains in Tennessee. Research suggests that the ecosystems of the future are unlikely to resemble the ecosystems that support existing society. The looming changes create significant risks for the individuals, communities, and whole countries that have built a way of life and the infrastructure to support it based on characteristics of existing ecosystems (Rolland et al., 2014). The increased disaster risk brought about by climate change, through increased severe weather events, sea level rise, and changed precipitation patterns, will further aggravate these impacts (Munang et al., 2013; Rolland et al., 2014). Ecosystem shifts will be a core challenge of climate change, and mitigating that challenge will require increasingly active management of ecosystems to preserve desired traits in existing ecosystems and to guide development of new ecosystems (Bork, 2021). In this context, ecosystem governance or ecosystem management means management of the whole ecosystem using a systems approach, not focused on a single species or single ecosystem benefit or other single aspect of the environment (Angelo and Glass, 2021).

Over the last 20 years, legal academia has developed a rich and diverse local ecosystem governance literature. For this review, which is largely focused on literature addressing local ecosystem governance in the United States, we define local ecosystem governance as generating shared vision for and exercising power over part or all of an ecosystem at a sub-national and generally sub-state scale, although we also include regional governance of ecosystems that cross state lines (Humby, 2014). The local ecosystem governance literature addresses ecosystems on state, tribal, and federal public lands and on private lands; most ecosystems span many property and jurisdictional boundaries. Law writers have addressed local ecosystem governance primarily in public land articles (e.g., Keiter, 2005; Colburn, 2006; Griffith, 2020), in articles addressing climate mitigation (e.g., Bianco et al., 2020) and adaption (e.g., Ruhl, 2010), in the new governance/resilience literature (e.g., Wiersema, 2008; Holley, 2010a; Arnold and Gunderson, 2013; Craig and Benson, 2013; Arnold, 2015), and in broader pieces about the future of environmental law in the anthropocene (e.g., Camacho, 2010; Bork, 2021). Many articles address local governance in an ancillary way or as part of a broader investigation, and far fewer articles take on local governance as a primary focus (examples include Hirokawa, 2011b; Salzman et al., 2014).

As this broad literature base suggests, local ecosystem governance has emerged as a go-to suggestion to address myriad ills in environmental decision-making. In many cases, it appears to be a plausible solution to intractable problems. Further, local cost/benefit analysis coupled with a robust understanding of ecosystem services can produce decisions that reflect local values while also protecting regional interests. Local governance is not a panacea, however (Porras, 2009), and the literature has been less successful in discerning exactly when and where it should be deployed. More broadly, although authors have been promoting local governance for many decades, local ecosystem governance has seen only limited adoption in practice. There is an implementation gap.

In spite of the promise of local governance, the diffuse nature of the literature in this area frustrates attempts at understanding the state of the art in the legal scholarship. It can also make accessing and understanding the primary pro and con arguments difficult, obscuring the many areas of broad consensus and the remaining areas of disagreement and leading to wasted research and writing effort. Legal scholarship in this area has also generally not been in dialog with the local environmental governance literature outside of the legal academy. For example, literature reviews in other disciplines that focus on ecosystem management, panarchy and ecosystem management, or governance of social-ecological systems often largely omit the legal literature (e.g., Folke et al., 2005; DeFries and Nagendra, 2017; Garmestani et al., 2020). Here, we seek to distill the legal literature on local environmental governance into a cohesive whole to both consolidate existing scholarship and to make this research more accessible outside the traditional legal literature channels. To maintain this focus, the review necessarily omits relevant work in many other fields, from conservation biology to land use planning, as beyond the scope of this review. We also omit or only briefly mention other topic areas that bear on local governance in the interest of providing a more complete review of the work directly on point; in most cases we provide citations to works that explore these other areas more fully. Finally, this is not a critical review; instead, we identify the many areas of broad agreement and disagreement about the promise and perils of local ecosystem governance and target several areas for additional research to advance this aspect of environmental law.

\section{METHODS}

This review focused on the local ecosystem governance literature published in U.S. law reviews from the year 2000 to March 2021. As noted above, we thus excluded articles in journals in other fields, informally published whitepapers, monographs, and books, among other media. A review of the older literature on this topic was done in Fischman and Hall-Rivera (2002), and the term "local environmental law" was coined in the early 2000s (Nolon, 2003b), so drawing a hard line beginning with the year 2000, while somewhat arbitrary, has some foundation in the literature. Moreover, our research suggested that significant pre-2000 works were generally reflected in the literature we did review. We also note that Salzman et al. (2014) have reviewed the urban ecosystem services literature. Our review did not specifically address the literature on sustainable building practices or other built environment approaches that integrate ecosystem management principles into construction and site design methods, in large part because the literature on green building is not typically framed in ecosystem management terms. We note that keeping human values relevant in ecosystem management has the potential to collapse the distinction between human needs in particular places and ecosystem functionality (Spyke, 2001; Beatley and Collins, 2002; Beatley, 2009). 
We performed Westlaw searches using the terms "Local Ecosystem Governance," "Environmental Governance," "Ecosystem Governance," and the combined search "local government," and "ecosystem management." We limited results to articles appearing in law reviews since the year 2000, and then reviewed all of the search results. While reviewing the selected articles, we examined their bibliographies in order to find additional relevant articles within the relevant time frame that our initial search parameters missed, again excluding non-law review publications. This approach is unlikely to produce an exhaustive list of all law literature that addresses local ecosystem governance; many articles mention it only briefly or in a tangential way, and some of those articles may escape our search approach. Nevertheless, it should provide a fairly comprehensive list. We reviewed over 140 articles, giving us a broad view of the law review articles addressing local ecosystem governance between 2000 and March 2021. Importantly, this approach is likely to capture all of the major trends and areas of agreement or disagreement within the field (Humby, 2014).

\section{RESULTS AND DISCUSSION}

We present the results of our literature review as a nested series of questions and answers. This allows for the easy evaluation of major areas of agreement and disagreement and provides a readable way to organize the voluminous legal literature on local ecosystem governance.

\section{Why Use Local Approaches for Ecosystem Governance?}

The literature clearly is unified in suggesting that the impacts of climate change require a reordering of humanity's relationship with nature. This requires decision makers to answer a host of new questions, including what aspects of ecosystems should be protected and what costs are acceptable when managing those ecosystems (Doremus, 2000). The literature is in substantial agreement that answering these questions will require new forms of governance (e.g., Colburn, 2006; Adler, 2007; Wiersema, 2008; Craig and Benson, 2013; Baker, 2015; Benson, 2015; Biber, 2017; Hirokawa, 2017). Most commentators agree that answering these questions should take place, at least in part, at a sub-national level, and often at a local level, although views on the appropriate sub-national governance unit vary significantly (Tarlock, 2002; Colburn, 2006; Salcido, 2012; Hirokawa, 2017; Bork, 2021).

The literature reflects a broad consensus that local approaches are indeed promising, but the reasons vary widely. Many authors evaluate the promise of local approaches based on the likelihood of achieving particular outcomes, either the traditional positive environmental outcomes (greater protection of native or total biodiversity, increased protection of relatively intact ecosystems, decreased carbon emissions, protection of historic baselines or otherwise valued conditions, etc.) (Tarlock, 1993; Nolon, 2012, 2016; Roesler, 2015) or outcomes that reflect a more complicated view of positive environmental outcomes (e.g., resilient ecosystems or reconciled ecosystems) (Ruhl, 2010, 2011; Arnold, 2014a, 2015). Many other authors take a positive view of local governance for process-based reasons, thinking them more likely to result in consensus decisions or more likely to produce community support for resulting decisions, to improve democratic functioning and civic engagement, or to better integrate the real costs and benefits of environmental decisions, among many other process-based views. A third category blends the first two: many authors suggest that local governance will produce better decision-making processes, which will, in turn, result in decisions with substantively better environmental outcomes. With these three broad groupings in mind, we examine the most common justifications for local ecosystem management below.

\section{Place-Based Considerations}

Many commentators argue for local ecosystem governance based on what might be termed "place-based considerations." These considerations go under many names, including bioregionalism (i.e., Doremus, 2001; Nicholson, 2010; Wilson, 2020), bioregional federalism (Nicholson, 2010), ecoscapes (Telesetsky, 2012), and place-based environmental law (Beatley and Collins, 2002; Hirokawa, 2017; Rosenbloom and Hirokawa, 2019). Although the terms have some subtle distinctions, we group the concepts together here because they offer many of the same arguments for local governance. We use the term place-based in this context, both because it is a broader category that may include both bioregionalism and ecoscapes (Adler, 1999; Telesetsky, 2013), and because it appears to have been embraced more broadly, based on Westlaw search results for all three terms.

\section{Emotional and Experiential Attachment}

The place-based arguments focus on two aspects of a sense of place. The first is psycho-emotional and experiential, relying on a human tendency toward emotional attachment to specific locations (Nolon, 2002a; Telesetsky, 2012; Hirokawa, 2017; William et al., 2020). People form emotional ties to the real places they inhabit, and they will be more likely to consider the benefits of environmental protection in political decisions affecting those places (Spyke, 2001; Nicholson, 2010). Even in cities, commentators suggest that a place-based urban land ethic will encourage people to better care for the land and engage governance through collective mindfulness and stronger connections between people, their environment, and their government (Berry, 2014). The place-based argument suggests that these ties increase support for environmental protection because people are willing to accept some costs and inconveniences for the sake of protecting, preserving, or enhancing a place of particular personal importance (Doremus, 2000; Hirokawa, 2017). As a corollary, Carpenter argues that federal law can supplant local environmental ethics, so that local people and government structures feel no need to take on environmental issues like endangered species, which are generally addressed by the federal government (Carpenter, 2011). Finally, place-based advocates suggest that local governance improves social commitment to environmental policies, with concomitant improvements in citizen monitoring of government follow through on environmental promises (e.g., Salcido, 2012; 
Telesetsky, 2012; see more discussion in the section Improving Governance Processes).

\section{Local Knowledge}

The second aspect of the place-based arguments focuses on local knowledge. These arguments concern knowledge of local ecosystems, or, less frequently, local values, and the local socialecological system (the way that the ecosystem and the local communities interact) (Spyke, 2001; Adler, 2005; Arnold, 2010; Hirokawa, 2017). This knowledge is vital for effective governance, the argument goes, because communities inherently interact with and shape their local environments.

One consistently referenced (but not fully explored) reason for promoting local ecosystem management concerns variation in ecosystem features across the nation. Variation in ecological systems make rational, one-size policies very difficult (Adler, 2005; Hirokawa, 2017) and also may undermine the effectiveness of federal environmental programs (Rosenbloom and Hirokawa, 2019; Bork, 2021). Importantly, because of the broad variation in local ecosystem circumstances, local ecosystem governance is an exercise in customizing successful approaches from other jurisdictions and innovating new ones, prompting Fox (2017) to assert that "innovative environmental protection may currently be more likely to occur at the local level than at any other." Local approaches can be customized to account to local variation in a way that blanket approaches cannot.

In terms of local values and social-ecological systems, people who live in a place experience that location differently than those who would regulate from afar, which in part explains why different levels of government regulate ecosystems so differently (Hirokawa, 2017). For example, Hirokawa documents differences between local and federal vision or policy statements and observes that federal statements generally portray the environment as an object, while local statements portray the environment as part of the community, an aspect of "home" (Id.). Even state-level governance may be too broad to understand local concerns (Salcido, 2012). Locals may value a place differently, and these values can best be recognized and preserved or enhanced by governance at a level that gives locals a strong voice. For example, local or locally involved planners may better understand how a city relates to its surrounding ecosystem (Spyke, 2001). Ecosystem governance is context dependent, and localities have their own unique histories and politics that will drive outcomes. Thus, local governance is an experiment in political questions and political will that derive from experience with the local environment, complicating uniform approaches (Doremus, 2001). The literature suggests that local governance can better account for those complications.

\section{Specialization}

Local governance that reflects local preferences for the level of protection or kinds of environments (Adler, 2005; Bork, 2018) can allow for environmental specialization (Salcido, 2012), with some localities focusing more on protection of native biodiversity while others focus on maximizing other ecosystem benefits. Bork notes that conservationists "will be able to protect some places, to maintain desired species and iconic ecosystems, through herculean feats of management and engineering, although this may require giving up other places almost entirely" (Bork, 2021). He argues that more marginal habitats or areas resistant to change may make for poor investments of conservation resources. Exiting trading schemes suggest that a robust "ecosystem marketplace" could ensure that environmental protection resources are allocated where they can make the biggest difference, based on both ecosystem and social system characteristics (Owen and Apse, 2014).

\section{Improving Governance Processes}

Many commentators argue that local ecosystem governance can realize the strengths of democracy better than governance at other levels. The literature reflects a broad divide among those who advance this argument-many commentators, reviewed in Adler (2005), argue for local ecosystem governance based on the subsidiarity principle, sometimes termed the matching principle, which holds that problems should be addressed at the most local level of government adequate to address the problem (see Butler and Macey, 1996; Monteiro de Lima Demange, 2013), with deference from other levels of government. Another group of commentators, the polycentrists, advocate an approach where local, state, and federal governments may all be regulating the same issue, with overlapping and sometimes competing authority, in order to capture the benefits of multiple perspectives and approaches for a given issue (e.g., Engel, 2006).

\section{The Matching Principle}

Advancing the matching principle, Adler (2005) argues that "[e]nvironmental protection efforts are most likely to be optimal where those who bear the costs and reap the benefits of a given policy determine how best, and even whether, to address a given environmental concern." Based on constitutional and federalism concerns, he would allocate "responsibility for most environmental problems to state governments with the hope, if not the expectation, that state governments would leave many concerns to local or regional authorities" (Id.). This may lead to less rent seeking behavior, or at least less sophisticated or successful rent seeking (Id.). Under this view, federal regulation makes sense where there is an institutional advantage for federal control, such as where the federal government has an economy of scale advantage (some science/technology generation or establishing national standards for data types and quality, for example) (Tal and Cohen, 2007), or where state and local governments cannot or will not address environmental problems due to issues like spillover effects or other externalities, whether related to pollution or use of common pool resources (Glicksman, 2010).

Keiter discusses this view extensively in his work on public lands (Keiter, 2005), where he blends in civic republicanism to argue that "public policy should be framed through civic dialogue at the level closest to those who will be affected by it" (Id.), where local, democratic dialogue "will tend inherently to accentuate public rather than private interests, and thus result in more public-spirited and better-accepted policies" (Id.). This idea marries a reinvigoration of local democracy with greater local control, the better to "manage the pressures created by the 
Anthropocene while remaining committed to the central values of the American political system" (Biber, 2017; see also Porras, 2009). The concept broadly mirrors arguments made in the field of "deliberative democracy" (Mouffe, 2000); in both cases, discussion and engagement mitigate political disagreements and conflict and increase participant buy in and acceptance of outcomes.

Building on these principles, matching-principle commentators sometimes argue that federalism concerns and the U.S. Constitution suggest a presumption for state responsibility and suggest that local environmental governance should often replace federal approaches. This justification for local control faces significant criticism from those arguing that local control leads to races to the bottom or results in suboptimal protection for other reasons (Jones, 2004). The race-to-thebottom issue, in particular, is an important challenge for those advocating for the primacy of local environmental governance. If increased local control leads to a race to the bottom, then local environmental governance is unlikely to produce the anticipated environmental improvements. In response, many subsidiarists argue that local and state governments had already begun to address environmental issues before the explosion of federal environmental law in the 1970s, and, more importantly, that local governments would have eventually managed to improve environmental conditions; Andreen provides an empirical counterpoint, showing that states were generally failing to improve or even maintain water quality and air quality before major federal statutes drove them to do so (Andreen, 2009, 2012). For additional background on this issue, see Engel (1996), Esty (1996), and Revesz (1997).

\section{Polycentric Governance}

The polycentrists argue that overlapping local, state, and federal programs provide multiple levels of oversight, produce more of the necessary research, and can better coordinate across multiple jurisdictions (Engel and Saleska, 2005; Cosens, 2010). Multiple levels of government likely view environmental problems in different ways and at different scales, and some commentators suggest this will generate more diverse environmental policies from regulators and stakeholders (Adelman and Engel, 2008). Further, by involving multiple levels of government in trying to solve the same problem, polycentrists suggest that the problem is less likely to go unsolved if one level of government is unable or unwilling to address it, making the governing system more resilient over time (Langridge, 2002; Arnold, 2014b; Farber, 2019), especially for "massive problems" (Ruhl and Salzman, 2010). Competition between levels of government may also make desirable regulatory activity more likely (Schapiro, 2005; Engel, 2006). Finally, polycentric governance plays a central role in adaptive governance in its many forms, from dynamic federalism to adaptive federalism to democratic experimentalism (Arnold, 2014a,b; Humby, 2014; Engel, 2017). The central concept in adaptive governance is local governance, coupled with a federal framework that sets and revises goals, such that local governments have the freedom to try different approaches. The best approaches could then be adopted and adapted by other local governments. The polycentric approach is susceptible to criticisms that highlight the potential for overlapping and contradictory regulatory approaches (Camacho, 2008), high transaction costs, difficulties in achieving consensus, and loss of economies of scale (Humby, 2014).

This schism between polycentrists and subsidiarists is important for a number of reasons. For subsidiarists, local governance should supplant existing federal regulation, offering local governments more freedom to choose whether and how to regulate environmental concerns. For polycentrists, local governance should supplement independent and overlapping federal authority, giving local governments leeway to experiment in the way they govern ecosystems, provided that the outcomes meet federally or state-established minimums. This divide relates in part to the aforementioned race-to-the-bottom issue. Both groups, however, see a strong role for local governance and highlight the power of local governments to serve as laboratories of democracy (Adler, 2005), as do many other scholars outside of this dichotomy (Colburn, 2006; Bianco et al., 2020). Local governments appear suited to the experimentation that governing ecosystems in the anthropocene will require (Rosenbloom and Hirokawa, 2019).

In spite of the underlying divide, both camps also appear to agree that some measure of local control makes ecosystem management more accountable (Rodriguez, 1997; Spyke, 2001; Adler, 2005; Cosens, 2010). Local interests may be more capable of closely tracking local issues and more inclined to follow through with decision makers (Cosens, 2010). Other scholars note that Elinor Ostrom's work suggests the place-based nature of local ecosystems allow successful communal resource management, perhaps even outside of traditional democratic structures (Carpenter, 2011; Biber, 2017). For a vigorous parochialism-based critique of the idea that local governance advances democracy, see Colburn (2006).

\section{Enabling Collaborative Governance}

Much of the work on local ecosystem governance addresses governance outside traditional governance structures. Most prominent in this area are the works addressing the growth and strengths of collaborative governance (e.g. Bradshaw, 2019). This form of governance is inherently local, and those promoting collaborative governance inherently advocate for a degree of local self-determination (Rodriguez, 1997). Rodriguez, for example, explores a model of inter-local expert agencies with the hope that such entities can shoulder the demands of selfdetermination and accountability, while engaging in sharing of resources, authority, and ecology (Rodriguez, 1997). We discuss collaborative approaches in more detail in the section Collaborative Governance.

\section{Local Government Powers Are Required for Ecosystem Management}

Many commentators suggest that local governance is a good fit for ecosystem management because local governments have the powers to constrain or encourage actions with significant ecosystem impacts. Prof. Nolon has been perhaps the biggest driver for broad recognition of the environmental impacts of local government as currently conceived, particularly land use 
controls, aesthetic ordinances, and growth controls, although much of his work has been outside of law reviews and falls outside of this review (Nolon, 2003a,b, but see Nolon, 2002a,b). Urban, suburban, or municipal control of real property is extensive, and rural county lands do not escape regulation. Fischman and HallRivera (2002) suggest that local governments are well-positioned to address land use change and to regulate widely dispersed small harms, both of which are core issues for ecosystem management. As Colburn (2006) notes, a local public's "right of self-direction" influences the core powers of modern local government and land use law (Biber, 2017). From exactions to zoning, local governments have governmental powers that makes legislators at other levels green with envy. Thus, "when local governments address the problems caused by industry, development, and growth, they wield tools that are uniquely situated locally and designed to assist local governments in protecting local values" (Hirokawa, 2017). This means that much of environmental law is inherently implemented as local law. For example, when commentators talk about shifting property law to accommodate the Anthropocene, they are talking about changes that may be most easily, or perhaps most constitutionally, accomplished at the local level (Biber, 2017; Sprankling, 2017; Bianco et al., 2020). Finally, enforcement of environmental law is inherently local, situated in a particular place and affecting particular people, and is already often carried out by local government entities or local or regional parts of state or federal entities (Rodriguez, 1997; Adler, 2005). Given the power advantages inherent in local governments, shifting some of the focus of ecosystem governance to those local governments may make sense.

Local governments will inevitably mediate adaption to ecosystem-associated climate risks. Local governments are responsible for providing and maintaining the public infrastructure, like roads, potable water, sewers, and open space, that allow human societies to thrive in harsh environments, so they must manage new development and ecosystemrelated disruption of this infrastructure (Rolland et al., 2014). Increasingly frequent and severe floods and droughts, or changes like sea level rise, present challenges that happen everywhere, but the impacts, particularly infrastructure impacts, are local in nature, placing local governments on the front lines of adaptation (Farber, 2009; Rolland et al., 2014). Whether local governments want to act or not, they will manage many aspects of adaptation (Whitely Binder, 2009).

\section{What Problems Are Likely to Arise in Local Ecosystem Governance?}

As the literature makes clear, local ecosystem governance offers many potential advantages over traditional approaches, based in part on the powers and nature of local governance. But these same aspects of local governance also produce some potential downsides and may increase the risk of some governance missteps. The literature documents these risks, based on both case studies and on more theoretical work. We have discussed a few problems in the section The Matching Principle, above (discussing the race-to-the-bottom and challenges to polycentric governance approaches), and we review other significant risks here.

\section{Lack of Agreement}

Advocates of local ecosystem governance suggest that local governance is a better place to hammer out an agreed vision for ecosystem condition, but this assumes that such agreements are always possible. For example, Adler observes many restoration efforts falsely assume that all uses and values can be maximized at the same time, and thus no stakeholders are willing to curtail their interests (Adler, 2007). This is a well-documented problem at the federal level, particularly in areas like national forest policy, and it is unlikely to be resolved simply by shifting management to the local level. In many cases, members of the local public may have strongly held and incompatible views for what ecosystems should be. This is particularly true in the anthropocene, which is likely to be characterized by ecosystems that are increasingly driven to the breaking point by human resource demands (e.g., Holley, 2015). Ecosystems are at risk when local governance fails to generate a shared vision or shared goals for the ecosystem of interest (Bork, 2021). Finally, even well-structured participatory processes do not guarantee participation leading to agreed outcomes in ecosystem management (Wilson, 2020).

\section{Poor Environmental Choices}

In some cases, poor environmental outcomes are even more concerning than the risk of achieving no agreements at all. From overgrazing under the Taylor Grazing Act's local grazing advisory boards to population collapses under local fishery management (Houck, 1997; Keiter, 2005), many past efforts at local ecosystem management have garnered participation and even agreement, but nonetheless produced poor environmental outcomes. The grazing advisory boards, for instance, prioritized management at a local scale by the resource users who depended on good range conditions, yet they permitted massive overgrazing and resource destruction (Keiter, 2005). Absent effective regulatory guardrails, local governance models may result in overconsumption or other undesirable ecosystem conditions due to a perceived competition between short-term returns and ecosystem productivity (Hirokawa and Dickinson, 2019). Even at a local scale, short term profits available from destructive decisions may frequently exceed easily identifiable costs (Doremus, 2000).

Scalar impacts play a role here as well. When the benefits of an action are likely to be felt in the short term and at a local level, and the costs of an action are more dispersed in space or time, rational actors are incentivized to take actions that would be suboptimal when viewed more holistically. Colburn (2006) argues that this is particularly true in local governments because of their "susceptibility to parochialism and protectionist regulation.” Farber $(2000,2019)$ likewise suggests that private local interests may often outweigh national interests in environmental protection. See the section Addressing Scale Issues for more discussion of scale issues. Of course, even when costs and benefits are both localized, some communities may choose outcomes that lead to levels of environmental destruction that others deem unacceptable. Tarlock (2002) points to the public utility duty, a perceived right to develop, deepseated expectations about property rights, and local government competition for high tax, low service land uses as factors leading to suboptimal environmental choices. These choices are also 
enabled by the techno-optimism that often infects environmental decision-making at all levels (Bork, 2021).

These issues are likely to be exacerbated by the magnitude of the ecosystem management required in the anthropocene. Because many ecosystems cannot be guided back to historic baselines, ecosystem management will require coming up with new targets for ecosystem management (Kammer, 2017; Bork, 2021). This risks what one commentator calls "a pornography of possibility, in which virtually any policy aim could be packaged and marketed to activate virtually any cultural worldview" (Kysar, 2008). An environmentalism unmoored from historic norms is daunting, and many commentators are concerned that local governance will lead to outcomes guided more by the public's fancy than by sound science and planning (Camacho, 2010).

Finally, implementing environmental solutions requires a change from past practices, which can make adoption of new approaches difficult. Dowd (2015), for example, argues that local governments are unlikely to adopt a green infrastructure approach of their own accord, in spite of the benefits of green infrastructure, due to barriers associated with "community engagement, and municipal staff education and training" or a tendency to give in to local opposition to change. Similarly, Harris (2018) notes that despite significant regional pressure to recognize and adapt to climate change, stormwater management planning and related capital projects in the Chesapeake Bay watershed still generally fail to account for future climate needs. Doing nothing avoids the tasks of gathering institutional resources, completing environmental reviews, or overcoming any of the myriad other hurdles that bar action. When active ecosystem management is required for risk mitigation, but the easy default is inaction, the level of regulation is likely to be suboptimal (Bosselman, 2001; Bork, 2021).

\section{Scale Issues}

Many commentators express concerns related to the scale of local governance. Scale concerns included externalities and spillover effects as noted above (Keiter, 2005), the small size of most local actions relative to large global problems, the scale of ecosystems relative to the jurisdiction of local governments, and arguments about the need for coordination actions across ecosystems over large areas (e.g., Salcido, 2012).

\section{Local Scale May Be Ineffective}

The small scale of many actions that can be accomplished at the local scale may discourage local action at all. Exceptionally large problems may paralyze local decision makers, or decision makers may decide that action by a single local entity would impose local costs with little local benefit (Doremus, 2000; Ruhl and Salzman, 2010). Even if local governance produces positive outcomes, many ecosystems stretch far beyond the boundaries of any one local jurisdiction, and action in one area would have little effect on the broader ecosystem (Telesetsky, 2012). This can also raise fairness concerns, when some localities impose more restrictions on their citizens in order to address problems that are not entirely of local origin (Keiter, 2005). Many environmental problemsclimate change, habitat loss affecting endangered species, water quality problems-are landscape level challenges that require landscape level actions (Colburn, 2006). Moreover, regulatory fragmentation can drive migration of people and land uses to less-regulated jurisdictions (Farber, 2009). As Wiener (2017) notes, state or local action remains ill-suited to addressing global conduct with global externalities. Some environmental problems do not lend themselves to resolution at a local scale (but see Engel and Orbach, 2008).

\section{Difficulties in Intra- and Inter-ecosystem Coordination}

Ecosystems of interest are often large enough that they fall under the jurisdiction of multiple local, regional, state, or even national governments, which makes governance exceptionally difficult (Bosselman, 2001; Camacho, 2008; Wilson, 2020). Ecosystem management in these settings will encounter significant bureaucratic, political, and preemption problems (Nolon, 2002a; Nicholson, 2010). Examples include overlapping and contradictory regulatory vehicles, intransigent governing entities, and a lack of the ecosystem-wide research, planning, and decision making that is required for successful ecosystem management. For example, salmon require a huge variety of intact habitats for their freshwater-ocean-freshwater life cycle, from clean, cold rivers to intact floodplains to healthy oceans. These requirements span many local jurisdictions, and successful conservation of salmon populations will require management for salmon protection in all of them (Kibel, 2017). Similar problems plague infrastructure issues: Subramanian (2016) argues that the watershed-wide demands of stormwater control demonstrate that Clean Water Act (CWA) tools like the MS4 and NPDES programs lead to fragmented, ineffective water quality control. The necessary degree of intra-ecosystem coordination may be difficult to achieve through local governance.

Extreme climate-related ecosystem changes are likely to require coordination between ecosystems as well. For example, Camacho and other commentators emphasize that shifts in climate conditions are likely to shift species home ranges over large geographic areas, and efforts to mitigate these shifts through assisted migration or habitat work will require a similarly large scope that can coordinate management of multiple ecosystems across many local jurisdictional boundaries (Camacho, 2010).

\section{Lack of Capacity}

Lack of adequate capacity will stymie efforts to increase governance of ecosystems at a local level. The capacity deficit may be institutional (non-existent or insufficient institutions, institutions lacking necessary regulatory authority, etc.), or based on insufficient expertise (scientific or otherwise) or funding levels.

\section{Lack of Institutional Capacity}

As discussed, local governments have a long history of lawmaking to manage particular aspects of local ecosystems. Nolon (2002a) offers a list of typical approaches for local environmental law: "cluster development; environmentally sensitive area protection; erosion and sediment control; grading, excavations, and fill, floodplain control; groundwater/aquifer resource protection; landscaping; ridgeline protection; scenic 
resource protections; soil removal; solid waste disposal; stream and watercourse protections; steep slopes; storm water management; timber harvesting; tree protection; vegetation removal; [environmental impact review] and wetlands." Notably absent? Species protections. Camacho (2017) found that, indeed, states generally have weak or nonexistent endangered species acts, relying instead on the Federal Endangered Species Act for species protection and funding. Stein and Gravuer (2008) found that only 32 states afford plant species protection, and most of those offered only weak protection. Species protection is an example of a broader problem: local governments may regulate for particular amenities of interest, but this approach ignores many issues important to ecosystem management. Regulating for particular ecosystem amenities is not the same as managing an ecosystem, and piecemeal regulations are not "genuine governance structures" (Farber, 2000; Nolon, 2002a). In many cases, local governance will require the creation of new governance structures or will require existing entities to take on new roles and responsibilities. And in cases where governments already engage in ecosystem-wide management, the management may be directed more toward serving local interests than meeting broader environmental goals (Nicholson, 2010).

In some cases, local governments may not have legal authority to engage in ecosystem management or may share that authority with other governing units, and contested or overlapping authority makes governing more difficult. Nolon (2002a), for example, advocates comprehensive management but notes that in some states, local governments have only those powers granted them by their state and require state-level enabling legislation. Kimmel (2014) describes failures of tribal governance when the tribes lacked sovereignty over their traditional territories. Tarlock (2002) noted that local governments often lack control over water rights, a key component of aquatic ecosystem protection, and suggested that local governments must have access to this power through cooperation with other government units for successful watershed governance. Even when granted power, local governments may not be willing to invest in the necessary governance structures without incentives or assistance from higher levels of government (Nolon, 2002a).

Finally, local governments that have the comprehensive authority to regulate ecosystem quality may be frustrated by state or federal preemption. Fox (2017) discussed this issue in another environmental context, highlighting the many states that have preempted local efforts to implement sustainable goals by, for instance, attempting to ban plastic straws or bags. Relatedly, other states have restricted local land use control over concerns about housing shortages (Stahl, 2020). This Achilles heel of local ecosystem governance is highlighted by other commentators as well (Colburn, 2006; Farber, 2008; Carpenter, 2011; Biber, 2017), and these concerns are addressed in sections The Matching Principle and Polycentric Governance, above. In sum, then, for a host of reasons, local governments may lack institutional capacity to govern ecosystems.

\section{Lack of Expertise}

Commentators note a lack of ecosystem expertise in local planning and building departments. One cause for this circumstance involves the occupation of the environmental regulatory space by the federal government in the 1970s. Much of the scientific focus shifted to the state and federal level, producing a growth in state and federal capacity. Nevertheless, state environmental agencies employ far more people than the federal EPA, and states perform most inspection or enforcement actions (Adler, 2005). Questions of community character (of a non-scientific nature) that are typically engaged by local planners have remained the province of local government, but local governments have not engaged scientific expertise at the same rate. Perhaps due to a lack of funding, planning departments in many local governments do not hire ecologists and biologists, and in response, local governments often must outsource environmental review in the project setting. Commentators suggest that technical assistance, performance incentives, shared and centralized expertise, and additional funding to hire experts will be required for successful local governance (e.g., Nolon, 2002a).

\section{Lack of Funding}

Many commentators express concerns about funding for local ecosystem governance. Beyond the funding for expertise identified above, ecosystem management is active management (Doremus, 2000), and it will be increasingly so in the anthropocene (Bork, 2021). Even with excellent planning for ecosystem management, implementing everything from new regulatory controls to the physical, on the ground weed pulling and other habitat manipulation requires significant funding (Id). In some cases, improved ecosystem governance may offer returns on investment in terms of improved infrastructure performance, enhanced ecosystem amenities, and improved ecosystem services, but these uncertain economic benefits may not provide sufficient incentive (Subramanian, 2016). If local governments have to foot the bill for enhanced local ecosystem governance, they are unlikely to address it of their own accord without significant and relatively certain benefits.

\section{Perpetuation of Existing Inequalities}

One final persistent and increasingly important issue highlighted by local governance scholars involves issues of equity in the distribution of natural capital and ecosystem service benefits across differently situated communities, including communities of color (Salzman et al., 2014). An equitable approach to ecosystem management requires local approaches: "Ecosystem management carries a price tag, and cities will have to address the distribution of costs and benefits" (Spyke, 2001). Despite early attention to the manner in which environmental justice challenges surface in local permitting (e.g., hazardous waste facilities, contaminated sites and prisons), the intersection of ecosystem management and equitable considerations is largely unaddressed in the literature on local governance. Yet, as Colburn (2006) notes, "[e]ven backers of local autonomy acknowledge its parochialism: virtually everyone acknowledges the role of local land use law in producing post-Brown racial and socioeconomic segregation." Hirokawa (2011b) has pointed out that suburban and affluent single-family residential properties offer more opportunities for ecosystem service benefits both under existing circumstances and as ecosystem investment 
opportunities. Denser, urban communities typically have less access to open space and less canopy cover from urban forests (in some cases, intentionally so; Braverman, 2008; Sullivan and Solomou, 2011). When, as anticipated in the anthropocene, even maintaining existing ecosystem services will take significant investment, it is likely that local governance will continue to perpetuate historical patterns of inequality. This is not a problem unique to local governance, and withholding local participation in environmental law may itself create environmental injustice situations (Fox, 2020). As local governments take on more of an environmental governance role, however, this issue requires continued action based on an actively anti-racist approach (Dillon and Sze, 2018).

\section{Promising Approaches to Mitigate Anticipated Problems}

Much of the environmental law literature focuses on a variety of ways to address the shortcomings of local governance. Here, we make a loose distinction between institutional approaches (including procedural approaches) vs. non-institutional ways to mitigate the negative aspects of local governance, following Wiersema (2008), and then discuss the most prominent approaches in each category. Other mitigation methods, which received less attention from legal commentators and so are not discussed in detail here, include increasing the clarity, accessibility, and transparency of decision processes; insulation of regulatory decision making from political influences; more rigorous scientific standards; and enhanced reviewability for most decisions.

\section{Institutional Approaches}

Much of the local governance scholarship has focused on institutional approaches, addressing the form and procedures scholars believe most appropriate to local ecosystem governance. Commentators ask much of these institutional approaches (Wiersema, 2008). Keiter (2005) provides a typical list of prinicples that good institutional structure should support in order to ensure fairness, accuracy, efficiency, and accountability. The principles are: transparent planning/decision processes, open to all interested participants; use of best available technical information and regular monitoring; clear and efficient planning and decision processes, with clear processes for appeals and amendments; and decisions that are both reviewable and enforceable (Id.). Beyond these fundamental principles, some commentators propose adjustments to the boundaries of existing jurisdictional units or some form of nested governance to mitigate potential local governance challenges.

\section{Redrawing Jurisdictional Boundaries}

Many scholars have suggested that aligning jurisdictional boundaries with meaningful ecosystem dimensions should be a central component of institutional reform (e.g., Adler, 1999; Doremus, 2001; Beatley and Collins, 2002; Buzbee, 2005; Nicholson, 2010; Telesetsky, 2012; Markell, 2016; and Wilson, 2020). This approach seeks to address scale problems and the lack of institutional capacity in existing governance units, while maximizing the psycho-emotional benefits of local governments.
Approaches advocating new governance institutions generally seek to better align jurisdictional boundaries with the larger scale governance needed to protect many ecosystem processes and with human environmental experiences. Nicholson (2010), for example, advocates a bioregional approach that aligns natural environmental boundaries with political units in order to better utilize a sense of place and produce self-organizing environmental governance systems. Similarly, Rosenberg (2006) suggests a regional ecosystem-based approach built around conservation of ecosystem services, with governing units defined around the intersection of ecosystem services and manageable human activities. Telesetsky (2012) advocates an "ecoscapes" approach that focuses on landscape units with "boundaries based on sustaining ecological functions and on protecting human needs for living landscapes." She calls on state governments to invest in ecoscapes-oriented restoration. Placebased science, education, recognition of local native groups, illustrations of a region as a whole ecosystem, and legal signals contribute to encouraging the regional sense of place needed for such efforts (Berry, 2014; Wilson, 2020), although much of the literature does not directly address development of the desired emotional connection to the land or otherwise operationalizing new institutional approaches. Commentators also note significant institutional roadblocks, including a lack of institutions with governing authority, "leaky" boundaries with regards to ecosystem services, and preemption issues, among other challenges. More research is needed on the types of governmental units that might govern, the source and scope of authority of these units, and how the jurisdiction of such entities can be coordinated with existing local governments.

The literature provides some examples where existing jurisdictional lines align with natural boundaries, allowing for more successful governance. McKinstry et al. (2012) examine Philadelphia's efforts to control its Combined Sewer Overflow (CSO) challenges. Philadelphia's Green City, Clean Waters program may be remarkable due to the coincidence of watershed geography and municipal authority to effectively finance green infrastructure investments (McKinstry et al., 2012). However, most local governments are not so well-situated, and McKinstry et al. (2012) note that the city-scale may offer few lessons in non-urbanized watersheds. Sonne (2014) suggests that, even within existing governance units, consolidation of authority over particular ecosystem or infrastructure attributes into a single agency could alleviate fragmentation. Other commentators suggest that simply expanding the scale of governance, rather than redrawing jurisdictional lines, could alleviate cross-jurisdictional pressures (Holloway et al., 2014; William et al., 2020).

Others provide examples of new organizations that have developed around regional ecosystems (e.g., Cosens, 2010), often motivated in part by federal environmental requirements (Guercio and Duane, 2009). Angelo and Glass (2021) explore an "Integrated Water Resources Management" (IWRM) approach to address fragmented decision-making, cross-jurisdictional inconsistencies, and inefficient and duplicative efforts, while making room for private stakeholder participation. They report on collaborative activities such as the Tampa Bay Estuary 
Program, which has engaged in a robust planning process and has highlighted a significant role for local governments in achieving its mission. Many other regional governance programs are unsuccessful, as described by Adler (2007) and Camacho (2008). This approach is not a panacea, but it offers promise in many cases. The question of when existing structures provide an adequate environmental governance framework (e.g., Nolon, 2002a) and when new structures are needed remains an active area of disagreement (see details in the section Areas of Future Research).

\section{Nested and Coordinated Governance}

Throughout the literature, attention is given to benefits of both top-down (Adams-Schoen, 2018) and bottom-up regulatory structures (Spyke, 2001), and both are offered as ways to capture ecosystem complexity in a way that simultaneously protects the system and individual (Wiersema, 2008) and communicates ecosystem value to local residents while countering negative human tendencies (Doremus, 2001). From this broad base, most commentators converge around the need for some degree of nested governance, involving significant local control, coordination among governance units, and state and federal backstops to local decision making (e.g., Wiersema, 2008). Scholars refer to this approach using a variety of terms, including cooperative federalism (traditional state-federal federalism) or cooperative subfederalism (federal-state-local federalism) (Owen, 2018), dynamic federalism (Ruhl and Salzman, 2010), nested governance (e.g., Bosselman, 2001), and multi-scalar or poly-centric governance (Ruhl, 2012). Much of this work fits within the polycentric governance approaches discussed in the section Polycentric Governance. The matching principle scholars (see the section on The Matching Principle) make up a vocal opposition minority. Even among scholars advocating for larger scale local governance, often regional governance that crosses state lines, most suggest that such structures would benefit from a national mandate and oversight from a central authority (Steinzor, 2000; Baur et al., 2008; Glicksman, 2010).

Nested governance structures aim to counter the scale, capacity, and poor environmental choice problems identified above by enabling guidance and coordination of local governance through substantive regional or national policies. Keiter (2005), for example, suggests a public land management approach with "definitive federal management standards" and substantial local flexibility, in order to promote shared responsibility for public lands. Owen suggests that the benefits of traditional cooperative federalism should justify similar state-local relationships, but he notes that few states have developed systems that utilize "local implementation with continuous state administrative oversight and review" which is necessary for this approach (Owen, 2018). Tarlock (2002) reviews examples of cooperative subfederalism experiments, pointing in particular to the Virginia and Maryland structures where the states have adopted specific mandates requiring local governments to adopt land use regulations to protect the Chesapeake Bay watershed.

Although some express concern that the power and parochial tendencies of local governments are unlikely to be effectively constrained by state or federal substantive standards (e.g., Keiter,
2005; Colburn, 2006), the majority of commentators agree that a nested governance approach can usefully cabin local authority, limit spillover effects, and combine the powers of local governance with the benefits of state or national standards.

\section{Iterative Management}

Virtually all commentators agree that ecosystem governance at any scale must be iterative, generally discussing this requirement within the framework of adaptive management (e.g., Karkkainen, 2002; Susskind et al., 2010; Ruhl, 2011; Arnold, 2014b; Baker, 2015; Rosenbloom, 2018). Adaptive management champions experimental and provisional decision making: data gathered from initial decisions leads to reevaluation of those decisions in an iterative cycle of policy making, ideally improving knowledge of the social-ecological system (Karkkainen, 2003). Adaptive management produces "comprehensive learning infrastructure that promotes the systematic monitoring, assessment, and adjustment of discretionary [decisions]" (Camacho, 2010). This approach is well-structured for making necessary decisions in the face of unresolvable uncertainty, which in many ways typifies ecosystem management in the anthropocene (Benson, 2015).

Arnold has been a forceful proponent of adaptive management, both in the narrower arena of watershed governance and in local environmental law more broadly. $\mathrm{He}$ and his coauthors propose "four features of an adaptive legal system: (1) multiplicity of articulated goals; (2) polycentric, multimodal, and integrationist structure; (3) adaptive methods based on standards, flexibility, discretion, and regard for context; and (4) iterative legal-pluralist processes with feedback loops, learning and accountability" (Arnold, 2014a). Other authors advocate similar approaches at a multitude of scales, from adaptive management to address single ecosystems (Koliba et al., 2016) to a broad dynamic and adaptive federalism approach to governance more generally (Adelman and Engel, 2008; Engel, 2017). Potential risks of adaptive management include an overemphasis on flexibility at the risk of real, enforceable protections (Doremus, 2001) and all-to-frequent failures in the learning and iterative portions of the adaptive management cycle; entities making environmental management decisions are often loath to reopen painful decision making processes once a decision is made, even if that decision is shown to be wrong.

\section{Non-institutional Approaches}

In contrast, many commentators suggest that institutions alone, no matter how well-designed, are not likely to maximize the benefits of local governance (Wiersema, 2008). Most scholars combine recommendations for institutional reform with recommendations for other elements essential to successful local ecosystem governance, and the lines between these categories are admittedly blurry.

\section{Collaborative Governance}

This "blurriness" is particularly apparent for collaborative governance, which can take place within traditional governance structures but which may be better fostered through approaches designed for it. Collaborative governance is a hallmark of the local governance literature. The term is widely used, 
yet there is no single model for collaborative environmental governance; at a minimum, collaborative governance involves stakeholder participation, adaptative processes, and collaboration across political boundaries. The literature consistently touts the benefits of collaborative management: better environmental outcomes, increased public support for difficult tradeoffs, more information, trust building, and win-win solutions (Susskind et al., 2010). Collaborative governance can address local governance problems related to lack of agreement, lack of capacity, perpetuation of existing patterns of inequality, and scale problems, if collaborations extend past traditional jurisdictional boundaries (Karkkainen, 2002). Bradshaw (2019) provides a very well-researched and detailed recent analysis of collaborative governance, including in the local governance setting.

In a piece focused on collaborative local governance, based on an analysis of Audited Self-Management in New Zealand and the Delta Plan in California, Holley (2015) argues that successful collaboration might include three policy-based themes: use of incentives to garner participation, including both economic incentives and "peer pressure;" limiting avenues for legal challenges to the results of the collaborative process; and building trust. In addition, Holley stresses the importance of integrating legal and collaborative mechanisms to insure a robust process (Id). Likewise, Wiersema observes that ecosystem management demands collaboration "by multiple stakeholders to allow broad participation, facilitate learning about these human factors, and provide a forum for determining the best policy and the values that society seeks to enhance" (Wiersema, 2008; Wiersema, 125253).

Susskind et al. (2010) provides a revealing analysis of the failure of collaborative adaptive management of Glen Canyon Dam. The circumstances appeared appropriate: Glen Canyon Dam benefitted from a well-funded research program addressing scientific uncertainty and was subject to differing perspectives among stakeholders, circumstances that should have benefitted from a collaborative process. Susskind et al. nonetheless observe that the project suffered from poor initial design, a lack of clear guidance from Congress on the relative priorities of competing goals, and a notable lack of commitment to resolving long-running conflicts; thus, the project benefitted from neither learning nor constructive engagement. Susskind et al. offer a framework for best practices: “(1) identifying appropriate stakeholder representatives; (2) involving stakeholders in developing a collaborative process; (3) using professional neutrals and encouraging consensus building; (4) incorporating joint fact-finding to deal with scientific uncertainty; (5) producing collectively supported written agreements; and (6) committing to build long-term management capabilities" (Id). These recommendations resonate with much of the literature on collaborative decision making.

\section{Education}

Many commentators argue that effective local governance requires increased education of local decision makers and the public. Camacho (2010) calls this education the "key endeavor" and advocates a "learning infrastructure" to ground the democratic process in usable science. Adler (2007) notes this is especially true in successful adaptive management, so that decision makers can integrate the new information produced by the adaptive management process and understand how it should affect additional management decisions. Scientific and traditional knowledge can help to constrain discussion about ecosystem management by providing information about what is possible in a given location, about real costs associated with restoration efforts (Hirokawa, 2017), about risks and likelihood of success, about historic conditions, about the non-obvious ecosystem services produced by local ecosystems and which in turn support local well-being, and about myriad other ecosystem aspects (Bork, 2021). In some cases, this information may help decision makers find better environmental solutions. Ideally, new information and understanding can help process participants find solutions that align their self-interest with the common good (Wiersema, 2008). Ultimately, while many ecosystem governance decisions are ultimately value judgements, education and sound science ensure that those value judgments are realistic, weigh more of the relevant factors, and are more likely to produce target outcomes. As Hirokawa notes, a more comprehensive understanding of ecosystem services "yields results that highlight local values and priorities. This is essentially the process of self-identity: self-reflection that encompasses sense of place" (Hirokawa, 2017).

\section{Enforceable Substantive Goals to Cabin Discretion}

Some commentators express concerns that local governments will produce suboptimal levels of environmental protection, resulting in spillover effects, disparate health and environmental outcomes, poor environmental protection, or other problems. These scholars suggest limits on local authority through substantive state, regional, or national standards. Substantive standards that address ecosystem function in the regulatory process, especially if combined with a reliable system of monitoring ecosystem degradation (Steinzor, 2000), can aid in identifying locally and regionally important ecosystems and ecosystem values, as well as provide a wealth of information about ecosystem vulnerabilities and "some assurance that interests vital to long-term protection of healthy ecosystems will be adequately taken into account" (Wiersema, 2008). For instance, Hirokawa discusses Washington's Growth Management Act (GMA) and the substantive criteria adopted by local governments to curtail habitat degradation under local critical habitat regulations, including standards requiring that new development approval be based on affirmative findings that habitat "functions and values" are maintained. Other local governments regulate developments to ensure no net loss of tree canopy or function (Hirokawa, 2011a). More broadly, standards can assist in drawing connections between otherwise independent development projects, such as by coordinating cumulative impact review of separate developments.

Wiersema suggests formulation of "a set of goals that will constrain decision makers both at the lower-level scales of governance and at the higher-level scales of governance" (Wiersema, 2008; 1294-95). Wiersema notes that the specificity required in these goals goes far beyond broad statements of resilience or ecosystem integrity (Id.). Resiliency, the new 
governance byword, is not a sufficient goal; "promoting resilience through ecosystem heath could include managing to protect at least some portion of all ecosystem components, only foundational species, or perhaps only species deemed to be socially valuable" (Camacho, 2010). Although much work remains in identifying effective substantive standards, most scholars agree that they will be needed.

\section{How Do We Encourage Successful Local Ecosystem Management?}

Given the general optimism about local governance in the literature, we turn to questions of how local governance can be encouraged. A great deal of the literature addresses encouraging local governments to take ecosystem management seriously, given that " $\mathrm{t}]$ he American local approach must ... be cobbled together with support from citizens and constituents who are unabashedly parochial" (Beatley and Collins, 2002), a challenge that Long (2009) asserts can only be overcome with desire, critical institutional awareness, and an ability to imagine. Some of the literature challenges this assumption. For instance, Rosenbloom and Hirokawa (2019) and Spyke (2001) argue that productive ecosystems and appropriate management often align with local interests and point out that local governments often focus on ecosystem benefits, even if it is not done in such terms (see also Nolon, 2002a). We begin with the question of whether much additional encouragement is needed.

\section{Current Trend Toward Increased Local Governance?}

Some evidence and authors suggest that there is an ongoing trend toward increased local ecosystem governance. Existing incentives for local ecosystem management, based on federal environmental laws, climate-related disasters, and other existing pressures, may be sufficient to encourage a much more significant role for local governance. Indeed, many scholars argue that local ecosystem governance is becoming normal. Although most scholars do not differentiate between protecting amenities and more wholesale governance (see the section Lack of Institutional Capacity), a number of authors do describe trends in wholesale ecosystem governance. For example, a variety of place-based governance models, particularly for aquatic ecosystems, emerged in the late 1990s: ecosystem-based management, collaborative governance, integrated watershed management, and adaptive management (Karkkainen, 2002; Holley, 2015; Angelo and Glass, 2021; see Rodgers, 2000). This growth responded to perceived failures (or at least intransigence) in traditional top-down governance; fading concerns about the likelihood of inadequate environmental protection by local governments; and a recognition that effective land conservation must be active, non-uniform, and encompass both private and public lands, all of which is within the purview of local governments (e.g., Tarlock, 2002).

Beyond aquatic ecosystems, Keiter notes that devolving authority to increase local or state control is a consistent theme in public land policy discussions, and he describes the ongoing growth of collaborative, consensus-based public land governance (Keiter, 2005; but see Colburn, 2006). Keiter cites many examples where new federal legislation was required to enable increased local governance but suggests that it will continue to grow as a successful ecosystem management approach. Hirokawa (2012) points out that some local governments are already making extra-territorial ecosystem investments to protect drinking water sources from forest fires.

More recently, Farber and Ruhl suggest a continuing trend toward local control to adapt to climate change impacts, whether or not the local governments have adequate governance capabilities to address the new roles thrust upon them (Farber, 2009; Ruhl, 2010). Under this view, the challenge is not how to encourage local governments to work on adaptation, but rather how to change environmental law to support and facilitate the increased responsibilities local governments will inevitably face. The emergent drivers increasing the role of local governments in climate adaptation, like increased impacts to local constituents from climate-change-related extreme weather, fire, sea level rise, and other calamites (Rolland et al., 2014), may not exist in the ecosystem governance context, where losses may be less obvious and feel less urgent.

Watershed problems may provide significant incentives to encourage local governance; governments must, by necessity, address drought and other impacts to water supply, which in turn necessarily implicates state or federally species protected impacted by the water delivery systems. Together, these concerns encourage aquatic ecosystem-wide scales of governance. Getches (2001) argues that states and local governments will act when faced with tangible near-term consequences of inaction in the water setting, most often in response to a crisis (perhaps climate related), but sometimes in response to federal regulatory pressures. The local watershed governance trend identified by authors in the 1990s and early 2000s continues (Arnold, 2010; Arnold et al., 2014), and other non-water examples illustrate local experiments with ecosystem-based approaches to land use regulation and extraterritorial planning (Hirokawa, 2012). This may be a race-to-the-top among local governments, at least among those localities that are actively engaging in ecosystem governance (Rosenbloom and Hirokawa, 2019), as some local governments are expressly, persuasively, and publicly linking quality of life improvements to ecosystem investments. Finally, Colburn (2006) argues that competition between regions, and in particular cities and suburban regions, will encourage meaningful ecosystem governance without interference. Nevertheless, in spite of the signs suggesting a natural trend toward local ecosystem governance, most commentators agree that existing trends toward enhanced local governance will be insufficient to address the challenges of the anthropocene. We thus turn toward approaches designed to encourage this approach.

\section{Ecosystem Services}

Ecosystem services approaches can encourage local attention to ecosystem management, leading to local ecosystem governance. "Ecosystem services" describes the conditions or processes provided by ecosystems that sustain or benefit human life (Guswa et al., 2014). Changing environmental conditions changes the services that the ecosystem provides, and accounting for the changes in ecosystem services provides a much clearer view of the real costs and benefits of, for example, local land use decisions. Accounting for these local costs and benefits allows 
service-maximizing ecosystem management to be integrated into the very idea of local governance (Hirokawa, 2017). Impacts that would be unnoticed on a national scale can loom large in a local setting (Id.) Local ecosystem services governance has become increasingly common under the guise of "lowimpact development" and "green infrastructure" (Holloway et al., 2014; Strifling, 2019), particularly in stormwater runoff, aquifer recharge, and urban forestry regulations. However, the literature also notes the adoption of other significant ecosystem services regulations, including support services such as geological stability, production services such as soil productivity, and cultural services such as locally special and historic places (Hirokawa, 2011a). If adopted more broadly, perhaps through a no-net-loss-in-ecosystem-services mandate, ecosystem services approaches can serve as a catalyst to operationalize local ecosystem governance (e.g., Carden et al., 2013).

\section{State or Federal Enabling Legislation or Administrative Actions and Support}

As discussed in sections Improving Governance Processes and Lack of Capacity above, local governments may lack authority to engage in ecosystem governance, or existing state or federal authorities may preempt or discourage local efforts. In the case of new governmental entities built around environmental boundaries, the entities themselves generally do not yet exist. Thus, the literature generally suggests that new state or federal legislation may be required (or at least be very helpful) for effective local governance in many instances. Bianco et al. (2020), for example, supports a change in federal preemption law to support local governance, suggesting that preemption should occur only rarely, and that Congress should expressly affirm state and local power to supplement federal standards with tighter local standards (see also Adelman and Engel, 2008; Farber, 2008). Bianco also emphasizes the need for policies promoting equitable outcomes for all, especially low income communities and disproportionately harmed people of color. Strifling (2019) provides a comprehensive history of water-related federalism issues and highlights "the need to create an enabling regulatory environment, ensure the availability of adequate resources, and build management capacity," while considering stakeholder feedback and addressing disproportionate impacts to vulnerable communities. This will likely initially increase transaction costs but may ultimately result in a more effective and efficient regulatory process (Id.). Roesler (2015) suggests federal intervention to prevent states from limiting local authority. In many cases, reforms may be administrative in nature. The Federal Endangered Species Act motivates many existing local ecosystem governance efforts in the literature, and administrative agencies could find ways to encourage these behaviors (e.g., Fischman and Hall-Rivera, 2002).

Scholars note that state or federal mandates must be accompanied by increased support to build local governance, scientific, and financial capacity. If successful local ecosystem governance will be active, adaptive, collaborative, and based on an ecosystem scale, it will require rigorous monitoring, comprehensive information gathering and dissemination, and periodic assessment and adaptation (e.g., Camacho, 2008; Farber, 2009; Angelo and Glass, 2021). This will require funds and other resources for building the information infrastructure and decision-making capacity for regional regulatory institutions (Id.), and may even require support for participation of third parties to actively engage in the policy-making process and hold decision makers and others accountable for successful outcomes (e.g., Xi et al., 2014).

\section{AREAS OF FUTURE RESEARCH}

Despite the growing body of literature on local ecosystem management, the research remains in early maturity. Much of the work has been theoretical, and the field would benefit from additional "empirical fieldwork to connect governance theory with grounded practice to identify what works, when, and how" (Holley, 2015). Although many authors have offered case studies of particular ecosystems, generalizable and broadly applicable results have been harder to extract. We also note that extensive research exists outside of the law reviews, and legal scholars should make more extensive use of that literature to deepen and enhance legal scholarship on this topic.

A few articles reviewed in this project set out specific research agendas to improve and normalize local ecosystem management. In particular, Karkkainen (2002) lays out a robust research agenda addressing collaborative governance, and virtually the entire agenda remains relevant to local ecosystem governance today. Getches (2001) suggests topics for local research must include the importance and content of leadership in communities that engage in ecosystem management, comparative analysis of consensus and majority rule decision making, the impacts of federal participation on collaborative decision making, and the significance of scientific and technical expertise for group effectiveness. Here we highlight additional areas for future research based on our review of the existing law literature.

\section{Environmental Justice}

As noted in the section Perpetuation of Existing Inequalities, the intersection of local ecosystem governance and equitable considerations is largely unaddressed in the literature. This is particularly concerning because, as this review indicates, local governance is likely to continue to grow, and it will have differential impacts on different parts of local communities. The literature also indicates that when governance of any kind fails to consider equity, explicitly, it perpetuates and deepens historical patterns of inequality. Scholars have suggested that new models of participation may be necessary to achieve equitable results (Crawford, 2009). We also note that the existing literature generally under-emphasizes tribal roles in ecosystem governance, which may provide a promising approach to addressing justice concerns in some cases. Avoiding inequitable outcomes will take additional research, self-examination, and a deep commitment to justice. 


\section{Science in Support of Local Ecosystem Governance}

The literature identifies many areas in which more scientific research is needed to inform ecosystem management. The literature also addresses some of the challenges of integrating science and values in decision making (Bork, 2021), although legal scholars could draw more on work in this area from other fields.

Some of the literature expressly identifies research agendas that will assist in the regulation of ecosystem productivity and disruptions in ecosystem processes. In addition to addressing research needed to address inequalities and payments for ecosystem services (PES) programs, Salzman et al. (2014) identify research needs: challenges of scale, identifying stakeholders, comprehensive regulations, ecosystem services trade-offs, enforcement, and adaptive management. As Salzman et al. suggest, more work needs to be done to coordinate scientific research and the knowledge needs of local governments and their local ecosystems. In addition, scientific research that coordinates regulatory triggers (e.g., specific permit standards applicable to activities that might take place in wetlands, floodplains, steep slopes, and habitat) to ecosystem functionality will allow for more predictive and effective regulation that incorporates performance standards (e.g., "safe to fail" approach to riparian areas and flood potential).

Largely unaddressed in the legal literature is the time scale of ecosystem management. The literature does address cumulative and synergistic impacts to ecosystems from particular projects, typically in the context of environmental review and urban sprawl (Hudson, 2017; Hirokawa and Dickinson, 2019). However, we were unable to identify research focused on the relevance of timescale of delayed or cascading impacts within any particular region. Research about the timing of impacts would provide critical insights for land-use planners, particularly given that the time scale the land-use planners can be 20 years or more from the present. This research will allow local governments to better anticipate the challenges produced from land-use decision making today, including a better grasp on the value of vacant lands and particular land uses in the ecosystem management context.

\section{Units of Governance}

As discussed in sections Improving Governance Processes and Institutional Approaches, there is little agreement on the geographical units of ecosystem governance and their relation to other levels of government. Some scholars defend the current form of local government (Fox, 2017), some scholars report on regional compacts (Markell, 2016), and some propose overlapping structures (Buzbee, 2005), modular structures (Freeman and Farber, 2005), cooperative structures (Strifling, 2019), top-down and bottom-up approaches (Tal and Cohen, 2007), or even conditions that produce successful collaboration (Holley, 2010b). This is an area ripe for continued research.

\section{Local Governance Fit for Particular Environmental Challenges}

In many areas of environmental concern, local governments have exercised land-use authority to control social, economic and environmental risks. There is less research, and a significant need for it, on (1) how land-use authorities might be used to address storm surges, pandemics, and other incidental impacts of climatic changes; (2) how local land-use authority can be exercised to improve the adaptive capacity of communities to the physical challenges of climate change and human in ecosystem migration; and (3) how much local participation can be expected. Two areas where the literature has been particularly critical of local outcomes concern floodplain management and storm water management.

More broadly, as noted in the section Local Scale May Be Ineffective, local governance is likely to be ineffective for some environmental problems, and more work is needed to identify those areas where local governance is likely to work especially well or especially poorly.

\section{Governance in Urban and Rural Settings}

The existing local governance literature often treats all local governments very similarly, failing to distinguish between rural and urban local governments. But local governance in a large city is different from local governance in a smaller town or a suburb, and governance across a whole county with both urban and rural areas is more different still. These differences are important, given the different environments in such jurisdictions, the different legal authorities granted to such governments, and the different ecosystem risks and needs in rural and urban areas. Of course, groundwater and watershed management approaches cross these boundaries (Langridge, 2009), yet rural and urban areas are geographically, conceptually, and legally different, and ecosystem management research should more effectively distinguish among different types of local governments.

\section{Persuading Landowners to Participate}

There is also a pressing need to understand environmental compliance behaviors (Raskin, 2015). Some scholars argue that perception and narrative are critical to the process of constructing norms around local ecosystem value. Braverman (2008) suggests that constructed values, such as race, consistently play a role in how communities view natural and artificial landscapes. Spyke (2001) suggests that changes can be made to the manner in which people interact with and within their cities by focusing on citizens' awareness of local nature and improving city "charm," "defined to be tied to both nature and the betterment of the human spirit," to develop willing ecosystem managers. Hirokawa (2017) argues that laws and values are constantly mediated by influences of identity, which is inherently local. Yet the literature offers few clues into constructing this identity or using local identity to build consensus in ecosystem management.

Research into the social and psychological influences driving reluctance is likely to provide critical insights into the framing of particular activities and programs (William et al., 2020). 
As Arnold (2014a) notes, we need a better understanding of how to persuade private landowners and businesses to make adaptive changes to their already-authorized practices. Why, for instance, do some farmers implement practices similar or even identical to Best Management Practices (BMPs), but nevertheless object to mandates for BMPs in their communities? Strifling (2019) suggests that unfamiliarity with green technologies and distrust drive reluctance. Similarly, Long (2009) argues that people, and their beliefs, present the main challenge to effective local ecosystem governance in the climate change context. Local ecosystem governance research should address these questions.

\section{Ecosystem Services and PES Programs}

Ruhl (2020) identifies three primary reasons that ecosystem services regulation has not figured in a more prominent fashion. First, he notes that ecosystem services "are, for all practical purposes, free," suggesting that there is little incentive to invest in ecosystem services benefits. Second, Ruhl points out that we suffer a lack of information at a granular level that would help us understand the impacts of many, if not most, biophysical changes. Third, Ruhl points out that institutional challenges might keep local governments from embracing rigorous ecosystem services policies, including the political boundaries that fragment control over ecosystem processes, which often separates actors from ecosystem service beneficiaries and can challenge political will. Hirokawa and Gottlieb (2012) observe that there may be another reason: in some ecosystems, non-use values may outweigh otherwise entrenched land use values.

Salzman et al. (2014) have identified several important research questions that could broaden understanding of how ecosystem services could fit into local governance and make ecosystem service analysis a more effective regulatory approach. First, they identify research needs relating to the distributional challenges of ecosystem service investments, such as urban forest cover, green infrastructure, and open space access. Second, they consider various elements of payment for ecosystem services (PES) programs and the difficulties in connecting public and private responsibility for making such investments, responsibilities that accrue to the beneficiaries of such investments, and the challenges inherent in accounting for and maintaining such benefits. This research need converges with non-legal research suggesting that the success of PES programs may strongly depend on design and context, where ill-formed programs may have counterproductive results. Third, Salzman et al. call for research on ecosystem governance, which they identify as "governmental, civil society and private market actors as well as the relationships between these actors and the legal and civil norms that they establish to address a particular need or interest" (Id.). In this context, questions relating to scale, participation, prioritization, and independent actors are matters for future research.
Another promising approach concerns benefit flows between jurisdictions in specific geographical areas (Ruhl, 2020). Data collection and analysis of the way ecosystem services and benefits flow from rural to urban areas could provide predictive approaches to managing the risks and benefits of upstream land development activities to other communities. Because the ecosystem services benefits at issue comprise an important component of community wellbeing, this research would facilitate communication and collaboration between communities-in particular, between rural communities and urban communities and their adjacent suburban neighborhoods.

\section{CONCLUSION}

Climate changes and other pressures on ecosystems require better ecosystem governance. Under future climate conditions, a wide of array of ecosystem characteristics will change, ending our passive reliance on functional ecosystems. Ecosystem shifts will be a constant, and how we govern ecosystem health will determine how well ecosystems support human life and well-being.

Ecosystem management has long been relegated to federal and state agencies, but we document the development over the last 20 years of a robust body of legal literature concerning the need for, challenges to, and form of local environmental law. In spite of the challenges we document, local ecosystem governance is a necessary component of any effort to face climate change and the accompanying challenges. Local governance offers benefits not available through other governmental structures.

\section{AUTHOR CONTRIBUTIONS}

Both authors listed have made a substantial, direct and intellectual contribution to the work, and approved it for publication.

\section{FUNDING}

Funding for research assistant support graciously provided by the UC Davis School of Law and the Albany School of Law.

\section{ACKNOWLEDGMENTS}

The authors appreciate the feedback from colleagues on this project, particularly Jonathan Rosenbloom and Shannon Roesler, and from the editors and the other authors of articles in this issue. The authors also deeply appreciate the hard work of their research assistants, Kathleen Anderson, Evan Levesque, and Sara Eddy. 


\section{REFERENCES}

Adams-Schoen, S. J. (2018). Beyond localism: harnessing state adaptation lawmaking to facilitate local climate resilience. Michigan J. Environ. Administr. Law 8, 185-244.

Adelman, D. E., and Engel, K. H. (2008). Adaptive federalism: the case against reallocating environmental regulatory authority. Minnesota Law Rev. 92, 1796-1850.

Adler, J. H. (2005). Jurisdictional mismatch in environmental federalism. N. Y. Univ. Law Rev. 14, 131-178. doi: 10.2139/ssrn.770305

Adler, R. W. (1999). Toward comprehensive watershed-based restoration and protection for great salt lake. Utah Law Rev. 1999, 101-204.

Adler, R. W. (2007). Restoring the environment and restoring democracy: lessons from the Colorado river. Virginia Environ. Law J. 25, 55-104.

Andreen, W. L. (2009). "Delegated federalism versus devolution: some insights from the history of water pollution," in Preemption Choice: The Theory, Law, and Reality of Federalism's Core Question, ed W. W. Buzbee (Cambridge: Cambridge University Press), 257-276.

Andreen, W. L. (2012). Of Fables and Federalism: A Re-Examination of the Historical Rationale for Federal Environmental Regulation. J. Environ. Law 42, 627-679.

Angelo, M. J., and Glass, J. W. (2021). Integrated estuary governance. William and Mary Law \& Policy Rev. 45, 455-534.

Arnold, C. A. (2010). Adaptive watershed planning and climate change. Environ. Energy Law Policy J. 5, 417-487.

Arnold, C. A. (2014a). Resilient cities and adaptive law. Idaho Law Rev. $50,245-264$.

Arnold, C. A. (2014b). Adaptive water law. University of Kansas Law Rev. 62, 1043-1090.

Arnold, C. A. (2015). Environmental law, episode IV: a new hope? Can environmentallaw adapt for resilient communities and ecosystems? J. Environ. Sustain. Law 21, 1-45.

Arnold, C. A., Green, O. O., DeCaro, D., Chase, A., and Ewa, J.-G. (2014). The social-ecological resilience of an eastern urban-suburban watershed: the anacostia river Basin. Idaho Law Rev. 51, 229-256. doi: 10.2139/ssrn.258 4968

Arnold, C. A., and Gunderson, L. H. (2013). Adaptive Law and Resilience. Environ. Law Rep. News Anal. 43, 10426-10443.

Baker, S. H. (2015). Adaptive law in the anthropocene. Chicago Kent Law Rev. $90,563-584$.

Baur, D. C., Parenteau, P. A., and Schorr, J. L. (2008). Legal Authorities for Ecosystem-Based Management in Coastal and Ocean Areas, Ocean and Coastal Law and Policy. Washington, DC: ABA Book Publishing.

Beatley, T. (2009). Biophilic urbanism: inviting nature back to our communities and into our lives. William Mary Law Policy Rev. 34, 209-238.

Beatley, T., and Collins, R. (2002). Americanizing sustainability: place-based approaches to the global challenge. William Mary Law Policy Rev. 27, 193-229.

Benson, M. H. (2015). Reconceptualizing environmental challenges-is resilience the new narrative? J. Environ. Sustain. Law 21, 99-126. doi: $10.2139 /$ ssrn. 2464386

Berry, M. M. (2014). Thinking like a city: grounding social-ecological resilience in an urban land ethic. Idaho Law Rev. 50, 117-151.

Bianco, N., Litz, F., Saha, D., Clevenger, T., and Lashof, D. (2020). New Climate Federalism: Defining Federal, State, and Local Roles in a U.S. Policy Framework to Achieve Decarbonization. Washington, D.C.: World Resources Institute.

Biber, E. (2017). Law in the anthropocene epoch. Georgetown Law J. 106, 1-68. doi: 10.2139/ssrn.2834037

Bork, K. (2018). Guest species: rethinking our approach to biodiversity in the anthropocene. Utah Law Rev. 2018, 169-235.

Bork, K. (2021). Governing nature: Bambi law in a WALL-E world. Boston College Law Rev. 62, 155-234.

Bosselman, F. (2001). What lawmakers can learn from large-scale ecology. J. Land Use Environ. Law 17, 207-325.

Bradshaw, K. (2019). Agency engagement with stakeholder collaborations, in wildfire policy and beyond. Arizona State Law J. 51, 437-504.

Braverman, I. (2008). "Everybody loves trees:" policing American cities through street trees. Duke Environ. Law Policy Rev. 19, 81-118.
Butler, H. N., and Macey, J. R. (1996). Externalities and the matching principle: the case for reallocating environmental regulatory authority. Yale Law Policy Rev. 14, 23-66.

Buzbee, W. W. (2005). Contextual environmental federalism. N. Y. Univ. Environ. Law Rev. 14, 108-129.

Camacho, A. E. (2008). Climate change and regulatory fragmentation in the great lakes Basin. Michigan State J. Int. Law 17, 139-154.

Camacho, A. E. (2010). Assisted migration: redefining nature and natural resource law under climate change. Yale J. Regul. 27, 171-255.

Camacho, A. E. (2017). Assessing state laws and resources for endangered species protection. Environ. Law Rep. News Anal. 47, 10837-10844.

Carden, K., White, C., Gaines, S. D., Costello, C., and Anderson, S. (2013). Ecosystem service tradeoff analysis: quantifying the cost of a legal regime. Arizona J. Environ. Law Policy 4, 39-87.

Carpenter, S. (2011). The devolution of conservation: why cites must embrace community-based resource management. Arizona J. Environ. Law Policy 2, 1-50.

Colburn, J. E. (2006). Localism's ecology: protecting and restoring habitat in the suburban nation. Ecol. Law Q. 33, 945-1014.

Cosens, B. (2010). Transboundary river governance in the face of uncertainty: resilience theory and the columbia river treaty. J. Land Resour. Environ. Law 30, 229-265.

Craig, R. K., and Benson, M. H. (2013). Replacing sustainability. Akron Law Rev. $46,841-880$.

Crawford, C. (2009). Our bandit future? Cities, shantytowns, and climate change governance. Fordham Urban Law J. 36, 211-252. doi: 10.2139/ssrn.1396310

DeFries, R., and Nagendra, H. (2017). Ecosystem management as a wicked problem. Science 356, 265-270. doi: 10.1126/science.aal1950

Dillon, L., and Sze, J. (2018). "Equality in the air we breathe: police violence, pollution, and the politics of sustainability, situating sustainabilities through interdisciplinary and social justice perspectives," in Sustainability: Approaches to Environmental Justice and Social Power, ed J. Sze (New York, NY: NYU Press), 246-270.

Doremus, H. (2000). The rhetoric and reality of nature protection: toward a new discourse. Washington Lee Law Rev. 57, 11-73.

Doremus, H. (2001). Adaptive management, the endangered species act, and the institutional challenges of new age environmental protection. Washburn Law J. 41, 50-89.

Dowd, E. A. (2015). Green infrastructure principles: an opportunity for streamlined stormwater and floodplain planning the west. Univ. Denver Water Law Rev. 19, 41-60.

Engel, K. H. (1996). State environmental standard-setting: is there a "race" and is it "to the bottom?" Hastings Law J. 48, 271-394.

Engel, K. H. (2006). Harnessing the benefits of dynamic federalism in environmental law. Emory Law J. 56, 159-188.

Engel, K. H. (2017). Democratic environmental experimentalism. UCLA J. Environ. Law Policy 35, 57-82. doi: 10.5070/L5351034670

Engel, K. H., and Orbach, B. Y. (2008). Micro-motives and state and local climate change initiatives. Harvard Law Policy Rev. 2, 119-137.

Engel, K. H., and Saleska, S. R. (2005). Subglobal regulation of the global commons: the case of climate change. Ecol. Law Quarterly 32, 183-233.

Esty, D. C. (1996). Revitalizing environmental federalism. Michigan Law Rev. 95, 570-653. doi: $10.2307 / 1290162$

Farber, D. A. (2000). Triangulating the future of reinvention: three emerging models of environmental protection. Univ. Illinois Law Rev. 2000, 61-81.

Farber, D. A. (2008). Climate change, federalism, and the constitution. Arizona Law Rev. 50, 879-924. doi: 10.2139/ssrn.1081664

Farber, D. A. (2009). Climate adaptation and federalism: mapping the issues. San Diego J. Clim. Energy Law 1, 259-286. doi: 10.2139/ssrn.1468621

Farber, D. A. (2019). Continuity and transformation in environmental regulation. Arizona J. Environ. Law Policy 10, 1-33. doi: 10.2139/ssrn.3338988

Fischman, R. L., and Hall-Rivera, J. (2002). A lesson for conservation from pollution control law: cooperative federalism for recovery under the Endangered Species Act. Columbia J. Environ. Law 27, 45-172.

Folke, C., Hahn, T., Olsson, P., and Norberg, J. (2005). Adaptive governance of social-ecological systems. Annu. Rev. Environ. Resour. 30, 441-473. doi: 10.1146/annurev.energy.30.050504.144511 
Fox, S. (2017). Home rule in an era of local environmental innovation. Ecol. Law Q. 44, 575-625. doi: 10.2139/ssrn.2916917

Fox, S. (2020). Localizing environmental federalism. Univ. California Davis Law Rev. 54, 133-194.

Freeman, J., and Farber, D. A. (2005). Modular environmental regulation. Duke Law J. 54, 795-912.

Garmestani, A., Twidwell, D., Angeler, D. G., Sundstrom, S., Barichievy, C., Chaffin, B. C., et al. (2020). Panarchy: opportunities and challenges for ecosystem management. Front. Ecol. Environ. 18, 576-583. doi: $10.1002 /$ fee. 2264

Getches, D. H. (2001). The metamorphosis of western water policy: have federal laws and local decisions eclipsed the states' role? Stanford Environ. Law J. 20, 3-72.

Glicksman, R. L. (2010). Climate change adaptation: a collective action perspective on federalism considerations. Environ. Law 40, 1159-1193.

Griffith, J. C. (2020). Institutional framework for open space conservation. J. Comp. Urban Law Policy 4, 235-286.

Guercio, L., and Duane, T. P. (2009). Grizzly bears, gray wolves, and federalism, oh my!: the role of the Endangered Species Act in de facto ecosystem-based management in the greater glacier region of Northwest Montana. J. Environ. Law Litigation 24, 285-366.

Guswa, A. J., Brauman, K. A., Brown, C., Hamel, P., Keeler, B. L., and Sayre, S. S. (2014). Ecosystem services: challenges and opportunities for hydrologic modeling to support decision making. Water Resour. Res. 50, 4535-4544. doi: $10.1002 / 2014$ WR015497

Harris, C. R. (2018). Green infrastructure for chesapeake stormwater management in a changing climate. Environ. Law Rep. News Anal. 48, 10150-10172.

Hirokawa, K. H. (2011a). Sustainability and the urban forest: an ecosystem services perspective. Nat. Resour. J. 51, 233-259. doi: 10.2139/ssrn.1722650

Hirokawa, K. H. (2011b). Sustaining ecosystem services through local environmental law. Pace Environ. Law Rev. 28, 760-826.

Hirokawa, K. H. (2012). Driving local governments to watershed governance. Environ. Law 42, 157-200. doi: 10.2139/ssrn.1926393

Hirokawa, K. H. (2017). Environmental law from the inside: local perspective, local potential. Environ. Law Rep. News Anal. 47, 11048-11064. doi: $10.2139 /$ ssrn. 3026186

Hirokawa, K. H., and Dickinson, D. (2019). The costs of climate disruption in the tradeoffs of community resilience. Western New Engl. Univ. Law Rev. $41,445-473$.

Hirokawa, K. H., and Gottlieb, C. (2012). Sustainable habitat restoration: fish, farms, and ecosystem services. Fordham Environ. Law Rev. 23, 1-54. doi: $10.2139 /$ ssrn. 1907721

Holley, C. (2010a). Facilitating monitoring, subverting self-interest and limiting discretion: learning from 'new' forms of accountability in practice. Columbia J. Environ. Law 35, 127-211.

Holley, C. (2010b). Removing the thorn from new governance's side: examining the emergency of collaboration in practice and the roles for law, Nested Institutions and Trust. Environ. Law Rep. News Anal. 40, 10656-10686.

Holley, C. (2015). Crafting collaborative governance: water resources, california's delta plan, and audited self-management in New Zealand. Environ. Law Rep. News Anal. 45, 10324-10337.

Holloway, C. F., Strickland, C. H., Gerrard, M. B., and Firger, D. M. (2014). Solving the CSO conundrum: green infrastructure and the unfulfilled promise of federal-municipal cooperation. Harvard Environ. Law Rev. 38, 335-370.

Houck, O. A. (1997). On the law of biodiversity and ecosystem management. Minnesota Law Rev. 81, 869-979.

Hudson, B. (2017). The natural capital crisis in Southern U.S. Cities. Chicago Kent Law Rev. 92, 529-547.

Humby, T.-L. (2014). Law and resilience: mapping the literature. Seattle J. Environ. Law 4, 85-130.

Jones, R. M. (2004). Dynamic Federalism: Competition, Cooperation and Securities Enforcement. Connecticut Insurance Law J. 11, 107-131.

Kammer, S. M. (2017). No-analogue future: challenges for the laws of nature in a world without precedent. Vermont Law Rev. 42, 227-296.

Karkkainen, B. C. (2002). Collaborative ecosystem governance: scale, complexity and dynamism. Virginia Environ. Law J. 21, 189-243.

Karkkainen, B. C. (2003). Adaptive ecosystem management and regulatory penalty defaults: toward a bounded pragmatism. Minnesota Law Rev. 87, 943-998.
Keiter, R. B. (2005). Public lands and law reform: putting theory, policy, and practice in perspective. Utah Law Rev. 2005,1127-1226.

Kibel, P. S. (2017). Damage to fisheries by dams: the interplay between International Water Law and International Fisheries Law. UCLA J. Int. Law Foreign Affairs 21,

121-150.

Kimmel, M. (2014). Fate control and human rights: the policies and practices of local governance in America’s arctic. Alaska Law Rev. 31, 179-210.

Koliba, C., Zia, A., Schroth, A., Bomblies, A., Van Houten, J., and Rizzo, D. (2016). The lake champlain basin as a complex adaptive system: insights from the research on adaptation to climate change. Vermont J. Environ. Law 17, 533-563.

Kysar, D. A. (2008). The consultants' republic: a review of ted nordhaus and michael shellenberger's break through: from the death of environmentalism to the politics of possibility. Harvard Law Rev. 121, 2041-2084.

Langridge, R. (2002). Changing legal regimes and the allocation of water between two california rivers. Nat. Resour. J. 42, 283-330.

Langridge, R. (2009). Confronting drought: water supply planning and the establishment of a strategic groundwater reserve. Univ. Denver Water Law Rev. $12,295-331$.

Long, J. (2009). From Warranted to Valuable Belief: Local Government, Climate Change, and Giving Up the Pickup to Save Bangladesh. Nat. Resour. J. 50, 743-800.

Markell, D. L. (2016). Emerging legal and institutional responses to sealevel rise in florida and beyond. Columbia J. Environ. Law 42, 1-57. doi: 10.2139/ssrn.2765569

McKinstry, R. B. Jr., Prior, H. D., Drust, J. E., Montalbán, A. C., and Magrini, K. D. (2012). Unpave a parking lot and put up a paradise: using green infrastructure and ecosystem services to achieve cost-effective compliance. Environ. Law Rep. News Anal. 42, 10824-10839. doi: 10.2139/ssrn. 1824530

Monteiro de Lima Demange, L. H. (2013). The principle of resilience. Pace Environ. Law Rev. 30, 695-810.

Mouffe, C. (2000). Deliberative Democracy or Agonistic Pluralism? Wien: Institut für Höhere Studien.

Munang, R., Thiaw, I., Alverson, K., Liu, J., and Han, Z. (2013). The role of ecosystem services in climate change adaptation and disaster risk reduction. Curr. Opin. Environ. Sustain. 5, 47-52. doi: 10.1016/j.cosust.2013.02.002

Nicholson, W. (2010). Getting to here: bioregional federalism. Environ. Law $40,713-764$.

Nolon, J. R. (2002a). In praise of parochialism. Harvard Environ. Law Rev. $26,365-416$.

Nolon, J. R. (2002b). Local land use controls that achieve smart growth. Environ. Law Rep. News Anal. 31, 11025-11078.

Nolon, J. R. (2003a). Open Ground: Effective Local Strategies for Protecting Natural Resources. Washington, D.C.: Environmental Law Institute.

Nolon, J. R. (2003b). New Ground: The Advent of Local Environmental Law. Washington, D.C.: Environmental Law Institute.

Nolon, J. R. (2012). Managing climate change through biological sequestration: open space law redux. Stanford Environ. Law J. 31, 195-249. doi: $10.2139 /$ ssrn. 1951907

Nolon, J. R. (2016). Enhancing the urban environment through green infrastructure. Environ. Law Rep. News Anal. 46, 10071-10086.

Odum, E. P., and Barrett, G. W. (2005). Fundamentals of Ecology, 5th Edn. Belmont, CA: Thompson Brooks/Cole.

Owen, D. (2018). Cooperative subfederalism. Univ. California Irvine Law Rev. $9,177-227$.

Owen, D., and Apse, C. (2014). Trading dams. Univ. California Davis Law Rev. 48, 1043-1108.

Porras, I. M. (2009). The city and international law: in pursuit of sustainable development. Fordham Urban Law J. 36, 537-601.

Raskin, E. (2015). Urban forests as weapons against climate change: lessons from California’s Global Warming Solutions Act. Urban Lawyer 47, 387-417.

Revesz, R. L. (1997). The race to the bottom and federal environmental regulation: a response to critics. Minnesota Law Rev. 82, 535-564.

Rodgers, W. H. Jr. (2000). The myth of the win-win: misdiagnosis in the business of reassembling nature. Arizona Law Rev. 42, 297-306.

Rodriguez, D. B. (1997). The role of legal innovation in ecosystem management: perspectives from American Local Government Law. Ecol. Law Quarterly $24,745-769$ 
Roesler, S. M. (2015). Federalism and local environmental regulation. Univ. Calif. Davis Law Rev. 48, 1111-1172.

Rolland, S. E., Pimentel, A., and Ganguly, A. (2014). Taking climate change by storm: theorizing global and local policy-making in response to extreme weather events. Buffalo Law Rev. 62, 933-977.

Rosenberg, A. (2006). Regional governance and ecosystem-based management of ocean and coastal resources: can we get there from here? Duke Environ. Law Policy Forum 16, 179-185.

Rosenbloom, J. (2018). Fifty shades of gray infrastructure: land use and the failure to create resilient cities. Washington Law Rev. 93, 317-384. doi: 10.2139/ssrn.3013831

Rosenbloom, J., and Hirokawa, K. H. (2019). Foundations of insider environmental law. Environ. Law 49, 631-657. doi: 10.2139/ssrn.3232217

Ruhl, J. B. (2010). Climate change adaptation and the structural transformation of environmental law. Environ. Law 40, 363-435.

Ruhl, J. B. (2011). General design principles for resilience and adaptive capacity in legal systems - with adaptations to climate change adaptation. North Carolina Law Rev. 89, 1373-1403.

Ruhl, J. B. (2012). Panarchy and the law. Ecol. Sociol. 17:31. doi: 10.5751/ES-05109-170331

Ruhl, J. B. (2020). Beyond green infrastructure-integrating the ecosystem services framework into urban planning law and policy. J. Comp. Urban Law Policy 4, 221-234.

Ruhl, J. B., and Salzman, J. (2010). Climate change, dead zones, and massive problems in the administrative state: guidelines for whittling away. Calif. Law Rev. 98, 59-120.

Salcido, R. (2012). The success and continued challenges of the yolo bypass wildlife area: a grassroots restoration. Ecol. Law Quarterly $39,1085-1134$.

Salzman, J., Arnold, C. A., Garcia, R., Hirokawa, K., Jowers, K., LeJava, J., et al. (2014). The most important current research questions in urban ecosystem services. Duke Environ. Law Policy Forum 25, 1-47.

Schapiro, R. A. (2005). Toward a theory of interactive federalism. Iowa Law Rev. 91, 243-317.

Scheffers, B. R., De Meester, L., Bridge, T. C. L., Hoffmann, A. A., Pandolfi, J. M., Corlett, R. T., et al. (2016). The broad footprint of climate change from genes to biomes to people. Science 354:aaf7671. doi: 10.1126/science.aaf7671

Sonne, B. (2014). Managing stormwater by sustainable measures: preventing neighborhood flooding and green infrastructure implementation in new orleans. Tulane Environ. Law J. 27, 323-350.

Sprankling, J. G. (2017). Property law for the anthropocene era. Arizona Law Rev. 59, 737-772.

Spyke, N. P. (2001). Charm in the city: thoughts on urban ecosystem management. J. Land Use Environ. Law 16, 153-197.

Stahl, K. (2020). Home rule and state preemption of local land use control. Urban Lawyer 50, 179-212. doi: 10.2139/ssrn.3485872

Stein, B. A., and Gravuer, K. (2008). Hidden in Plain Sight: The Role of Plants in State Wildlife Action Plans. Arlington, VA: NatureServe.

Steinzor, R. I. (2000). Devolution and the public health. Harvard Environ. Law Rev. 24, 351-463.

Stokstad, E. (2009). On the origin of ecological structure. Science 326, 33-35. doi: 10.1126/science.326_33

Strifling, D. A. (2019). Integrated water resources management and effective intergovernmental cooperation on watershed issues. Mercer Law Rev. 70, 399-435.
Subramanian, R. (2016). Rained out: problems and solutions for managing urban stormwater runoff. Ecol. Law Q. 43, 421-448.

Sullivan, E. J., and Solomou, A. (2011). "Preserving forest lands for forest uses" land use policies for oregon forest lands. J. Environ. Law Litigation. 26, 179-258.

Susskind, L., Camacho, A. E., and Schenk, T. (2010). Collaborative planning and adaptive management in glen canyon: a cautionary tale. Columbia J. Environ. Law 35, 1-55.

Tal, A., and Cohen, J. A. (2007). Bringing "top-down" to "bottom-up:" a new role for environmental legislation in combating desertification. Harvard Environ. Law Rev. 31, 163-217.

Tarlock, D. (1993). Local government protection of biodiversity: what is its niche? Univ. Chicago Law Rev. 60, 555-613. doi: 10.2307/160 0079

Tarlock, D. (2002). The potential role of local governments in watershed management. Pace Environ. Law Rev. 20, 149-176.

Telesetsky, A. (2012). Ecoscapes: the future of place-based ecological restoration laws. Vermont J. Environ. Law 14, 493-548. doi: 10.2307/vermjenvilaw.14.4.493

Telesetsky, A. (2013). Restoration and large marine ecosystems: strengthening governance for an emerging international regime based on "ecoscape" management. Univ. Hawaii Law Rev. 35, 735-767.

Whitely Binder, L. (2009). Preparing for Climate Change in the U.S. Pacific Northwest. Hastings West Northwest J. Environ. Law Policy 15, 183-195.

Wiener, J. (2017). Think globally, act globally: the limits of local climate policies. Univ. Pennsylvania Law Rev. 155, 1961-1979.

Wiersema, A. (2008). A train without tracks: rethinking the place of law and goals in environmental and natural resources law. Environ. Law 38, 1239-1300.

William, R., Endres, A. B., and Stilwell, A. S. (2020). Integrating green infrastructure into stormwater policy: reliability, watershed management, and environmental psychology as holistic tools for success. UCLA J. Environ. Law Policy 38, 37-59. doi: 10.5070/L5381047118

Wilson, K. (2020). Governing the Salish Sea. Hastings Environ. Law J. 26, 169-181. Xi, W., Butzel, A. K., Ottinger, R. L., Robinson, N. A., Parker, J. L., Rucinski, T. L., et al. (2014). Assessing environmental governance of the hudson river valley: application of an IPPEP model. Pace Environ. Law Rev. 31, 1-104.

Conflict of Interest: The authors declare that the research was conducted in the absence of any commercial or financial relationships that could be construed as a potential conflict of interest.

The reviewer EB declared a shared affiliation with one of the authors $K B$, to the handling editor at time of review.

Publisher's Note: All claims expressed in this article are solely those of the authors and do not necessarily represent those of their affiliated organizations, or those of the publisher, the editors and the reviewers. Any product that may be evaluated in this article, or claim that may be made by its manufacturer, is not guaranteed or endorsed by the publisher.

Copyright (c) 2021 Bork and Hirokawa. This is an open-access article distributed under the terms of the Creative Commons Attribution License (CC BY). The use, distribution or reproduction in other forums is permitted, provided the original author(s) and the copyright owner(s) are credited and that the original publication in this journal is cited, in accordance with accepted academic practice. No use, distribution or reproduction is permitted which does not comply with these terms. 